\author{
아질산염과 녹차 추출물의 첨가에 따른 김치 발효 소시지의 미생물 및 \\ 이화학적 품질 특성 비교 \\ 강선문 $^{1} \cdot$ 김태실 $^{2} \cdot$ 조수현 $^{1} \cdot$ 박범영 $^{1} \cdot{\text { 이성기 }\left.\right|^{2}}^{*}$ \\ ${ }^{1}$ 농촌진흥청 국립축산과학원, ${ }^{2}$ 강원대학교 동물식품응용과학과
}

\title{
Comparison of Microbial and Physico-chemical Quality Characteristics in Kimchi-fermented Sausages with Sodium Nitrite and Green Tea Extract
}

\author{
Sun Moon Kang ${ }^{1}$, Tae Sil Kim ${ }^{2}$, Soohyun Cho ${ }^{1}$, Beomyoung Park ${ }^{1}$ and Sung Ki Lee ${ }^{2} *$ \\ ${ }^{1}$ National Institute of Animal Science, Rural Development Administration, Suwon 441-706, Korea, ${ }^{2}$ Department of Animal \\ Products and Food Science, Kangwon National University, Chuncheon 200-701, Korea
}

\begin{abstract}
This study was conducted to compare the microbial and physico-chemical quality characteristics in Kimchi-fermented sausages added with sodium nitrite (SN) and green tea extract(GTE). The sausages were fermented at $24^{\circ} \mathrm{C} / \mathrm{RH} 89 \%$ for $17 \mathrm{hr}$ and then dried at $10^{\circ} \mathrm{C} / \mathrm{RH} 70 \sim 80 \%$ for 9 days. The total bacteria count, lactic acid bacteria count and $\mathrm{pH}$ value ranged from 8.7 Log $\mathrm{CFU} / \mathrm{g}$ sausage, 8.1 8.3 $\mathrm{Log} \mathrm{CFU} / \mathrm{g}$ sausage and 4.35 4.36, respectively, at $9 \mathrm{~d}$ of ripening, but did not show significant differences during ripening among all sausages. The lipid oxidation (TBARS) was inhibited by both GTE and SN, but GTE had lower $(\mathrm{p}<0.05)$ inhibitory effect, compared with SN. The $b^{*}$ value of GTE-added sausage was higher than that of the control sausage, but $\mathrm{a}^{*}$ and $\mathrm{b}^{*}$ values of $\mathrm{SN}$-added sausage remained higher than other sausages during ripening. Therefore, it had lower effect on lipid oxidation and color stabilities than SN while GTE improved the lipid oxidation stability in Kimchi-fermented sausage. However, both GTE and SN did not influence the growth of lactic acid bacteria.
\end{abstract}

(Key words : Green tea extract, Sodium nitrite, Kimchi-fermented sausage, Lipid oxidation, Color, Lactic acid bacteria)

\section{서 론}

김치 발효 소시지는 김치 자체를 향신료와 함께 원료육에 첨가하 여 발효 및 건조시킨 한국형 발효 육제품이다(Lee 등, 1990). 김 치에는 Pediococcus, Leuconostoc, Lactobacillus 와 같은 내냉성 및 내염성 (Hugas와 Monfort, 1997)의 특성을 가진 젖산균들이 풍부하여 발효 소시지의 스타터 첨가물로서 매우 유용하다. 또한 김치에 함유된 젖산균들의 대사물 (유기산, 비타민 $\mathrm{B}$, 비타민 $\mathrm{C}$, 덱스트란, 아세틸콜린, 박테리오신 등)과 세포벽 성분(테이코산, 리 포테이코산, 글리코펩타이드 등) (Park과 Cheigh, 2000)은 항산화, 항암, 항고혈압, 항비만, 항혈전, 항균 등의 다양한 생리적 효과를 가지고 있으므로(Choi 등, 1999; Lee와 Cheigh, 1995; Noh 등, 1999; Sheo와 Seo, 2004; Yu 등, 2009) 김치 발효 소시지는 인 간의 건강에 유익한 probiotics 뿐만 아니라 기능성 육제품으로서 그 가치가 매우 높다.

아질산염은 염지 육제품의 필수적인 첨가제로서 발색, 조직감 및
풍미의 증진, Clostridium botulinum 등의 식중독균 및 부패 미생 물의 생장 억제, 지방산화의 억제와 같이 매우 중요한 기능을 가지 고 있다(Cassens, 1997; Fleybler 등, 1993). 하지만 과다 섭취할 경우 amine과의 반응에 의한 $n$-nitrosamine이라는 발암 물질의 생 성과 methemoglobin의 생성에 의한 청색증을 유발하므로 인간의 건강에 매우 유해하다고 보고되고 있다(Chow와 Hong, 2002; Mirvish 등, 2000). 이러한 아질산염의 부정적 효과는 소비자들로 하여금 육가공제품의 안전성에 대해 부정적인 인식을 갖게 하였고, 이에 따라 인간의 건강에 무해하면서 유익한 천연 물질로의 대체가 요구되고 있다(Bloukas 등, 1999). 천연물 첨가제의 조건은 역사 적으로 오랜 기간 동안 이용되어온 식물로서 성분을 추출할 때 어 떠한 화학적 반응을 일으키지 않아야 하며 (Francis, 1987), 현재까 지 녹차, 로즈메리, 오레가노, 세이지, 옻나무, 포도씨, 토마토 등의 여러 식물 자원들이 이용되고 있다(Bañón 등, 2007; Deda 등, 2007; Hernández-Hernández 등, 2009; Kang 등, 2011; Mohamed 등, 2011).

* Corresponding author: Sung Ki Lee, Department of Animal Products and Food Science, Kangwon National University, Chuncheon 200-701, Korea. Tel: +82-33-250-8646, Fax: +82-33-251-7719, E-mail: skilee@kangwon.ac.kr 
녹차는 epicatechin, epicatechin gallate, epigallocatechin, teaflavin gallate, teaflavin monogallate $\mathrm{A}$ 및 $\mathrm{B}$, teaflavin digallate 등의 폴리페놀 화합물을 풍부하게 함유하고 있고(Kuroda 와 Hara, 1999; Wanasundara와 Shahidi, 1996), 이중 epigallocatechin이 주성분인 catechin의 $65 \%$ 를 차지하고 있으며, 대부분의 약리적 효과는 epicatechin 계열 물질들과 관련 있다 (Chu와 Juneja, 1997). 또한 항산화, 항암, 항노화, 항동맥경화, 항 비만, 항균 등의 생리활성을 가지고 있으며 (Coyle 등, 2008; Zaveri, 2006), 양념육, 패티, 소시지 및 발효 육제품 등의 다양한 가공 제품의 기능성 첨가물로도 많이 활용되고 있다(Bozkurt, 2006; Jo 등, 2003; Kim 등, 2010; McCarthy 등, 2001; Mitsumoto 등, 2005; Yang 등, 2006).

따라서 본 연구는 김치 발효 소시지에서 아질산염과 녹차 추출물 의 첨가가 미생물 및 이화학적 품질 특성에 미치는 효과를 비교하 고자 실시하였다.

\section{재료 및 방법}

\section{1. 실험용 김치 발효 소시지의 제조 및 실험설계}

실험용 김치 발효 소시지는 Table 1 의 배합 조성과 같이 제조하 였다. 원료육과 김치는 강원도 춘천 소재 $\mathrm{N}$ 마트로부터 도축한 지 3 일된 한우 암소 $\left(1^{+} \mathrm{A}\right.$ 등급)의 우둔 (M. semitendinosus $)$ 과 배추 김치 (Chongga Poggi Kimchi, Daesang FNF Co., Ltd., Korea) 를 구입하였으며, 등지방은 강원도 춘천 소재 $\mathrm{H}$ 육가공업체로부터 냉동 돼지 등지방을 구입하여 이용하였다. 아질산염 $(237213, \geq$ $97.0 \%, \mathrm{ACS}$ reagent $)$ 과 녹차 추출물 $(\geq 20 \%$ catechin, $\leq 5 \%$ caffeine)은 각각 시그마알드리치사(Sigma-Aldrich, USA)와 (주바

Table 1. The formulas of experimental Kimchi-fermented sausages

\begin{tabular}{lrcc}
\hline \multirow{2}{*}{ Ingredients } & \multicolumn{3}{c}{ Treatments } \\
\cline { 2 - 4 } & Control & $\begin{array}{c}\text { Sodium } \\
\text { nitrite }\end{array}$ & $\begin{array}{c}\text { Green tea } \\
\text { extract }\end{array}$ \\
\hline \hline Lean beef & 1,600 & 1,600 & 1,600 \\
Pork backfat & 400 & 400 & 400 \\
Baechu-Kimchi & 100 & 100 & 100 \\
Sodium nitrite & - & 0.223 & - \\
Green tea extract & - & - & 0.889 \\
Salt & 40 & 40 & 40 \\
Sugar & 32 & 32 & 32 \\
Fresh garlic & 20 & 20 & 20 \\
Fresh ginger & 12 & 12 & 12 \\
Black pepper powder & 12 & 12 & 12 \\
Fermented sausage spice & 6 & 6 & 6 \\
\hline
\end{tabular}

이오랜드(Bioland Co., Korea)로부터 구입하였다. 발효 소시지를 제조하기 앞서 우둔의 등지방과 결체조직, 혈액을 제거한 후 육세 절기 (M-22, Daewoo Kitchen Co., Korea)를 이용하여 우둔 살코 기, 돼지 등지방 및 배추 김치를 $6 \mathrm{~mm}$ 로 세절하였다. 제조 과정 시 열 발생을 최소화하기 위해 세절육 $(\mathrm{pH} 5.53$ 수분: $71.9 \%$, 조 지방 : 4.6\%) $1,600 \mathrm{~g}$ 과 세절 등지방 $400 \mathrm{~g}$ 을 $-20^{\circ} \mathrm{C}$ 에서 3 시간 동안 냉각한 후 가장 첫 번째로 silent cutter(OSK 10600, Ogawa Seiki Co., Ltd., Japan)에 세절육과 소금(Sajo Haepyo Co., Ltd., Korea) $40 \mathrm{~g}$, 백설탕 (CJ Cheiljedang Corp., Korea) $32 \mathrm{~g}$, 다진 생마늘 $20 \mathrm{~g}$, 다진 생강 $12 \mathrm{~g}$, 흑후추 가루(Ottogi Ltd., Korea) $12 \mathrm{~g}$, 발효 소시지용 향신료 (Muster, Cervelat Gewürz 604, Chr. Hansen GmbH, Switzerland) $6 \mathrm{~g}$ 을 넣고 3분 동안 혼합하였다. 이후 세절한 배추 김치 $(\mathrm{pH} 4.08$, 수분 : $90.3 \%$ 총균수 : $8.8 \mathrm{Log} \mathrm{CFU} / \mathrm{g}$ 젖산균 : $8.3 \mathrm{Log} \mathrm{CFU} / \mathrm{g}) 100 \mathrm{~g}$ 을 넣 고 3 분 동안 혼합한 다음 최종적으로 세절 등지방 $400 \mathrm{~g}$ 을 넣고 1 분 동안 혼합하였다. 아질산염과 녹차 추출물은 김치와 함께 혼합 하였으며, 최종 혼합물 $2,222 \mathrm{~g}$ 의 $100 \mathrm{ppm}$ 과 $400 \mathrm{ppm}$ 이 되도록 각각 $0.230 \mathrm{~g}$ 및 $0.889 \mathrm{~g}$ 을 첨가함으로서 무첨가구인 대조구와 함 께 3 개의 처리구들을 제조하였다. 최종 소시지 혼합물은 $\varnothing 80 \mathrm{~mm}$ 의 cellulose casing (Teepak Co., USA)에 충진하여 $1{ }^{\circ} \mathrm{C}$ 에서 12 시간 동안 염지한 후 항온항습기(VC 2057, Vötsch Industrietechnik, Germany)에서 9일간 숙성시켰다. 실험 소시지의 숙성은 $24^{\circ} \mathrm{C} / \mathrm{RH} 89 \%$ 의 조건에서 소시지의 $\mathrm{pH}$ 가 4.9 로 도달하는 시점인 17 시간까지 발효시키고, $10^{\circ} \mathrm{C} / \mathrm{RH} \quad 80 \%$ 의 조건으로 변경하여 3 일 간 건조시킨 후 다시 $\mathrm{RH}$ 를 3 일 간격으로 $5 \%$ 씩 감소시켜 최종 1 $0{ }^{\circ} \mathrm{C} / \mathrm{RH} 70 \%$ 의 조건이 되도록 하였다. 미생물 및 이화학적 품질 분석은 숙성 0 시간, 17 시간, 3 일, 6 일 및 9 일에 한 처리구당 3 개의 소시지에서 채취하여 실시하였다.

\section{2. 총균수 및 젖산균수 측정}

시료 $10 \mathrm{~g}$ 과 $90 \mathrm{~mL}$ 의 $0.1 \%(\mathrm{w} / \mathrm{v})$ peptone 멸균수를 멸균백 (Whirl-pak ${ }^{\circledR}$ blender bag, Nasco International Co., USA)에 넣어 stomacher(Laboratory blender 400, Seward Co., England)로 highspeed에서 1 분 동안 균질한 다음 $1 \mathrm{~mL}$ 를 채취하여 $0.1 \%$ (w/v) peptone 멸균수로 적정 희석 배수까지 희석하였다. 이후 희 석액 $1 \mathrm{~mL}$ 을 plate count agar(Difco Laboratories, USA)와 $0.02 \%(\mathrm{w} / \mathrm{v})$ sodium azide를 첨가한 Lactobacilli MRS agar (Difco Laboratories, USA)에 접종하여 각각 $37^{\circ} \mathrm{C}$ 및 $32^{\circ} \mathrm{C}$ 에서 48시간 동안 배양하였다. 최종 결과는 colony가 30 300개인 희석 배수에서 계수한 후 시료 $1 \mathrm{~g}$ 당 $\log \mathrm{CFU}$ 로 산출하였다.

3. $\mathrm{pH}$ 측정

$\mathrm{pH}$ 는 시료 $10 \mathrm{~g}$ 과 증류수 $90 \mathrm{~mL}$ 를 균질기 (PH91, SMT Co., Ltd., Japan)로 $10,000 \mathrm{rpm}$ 에서 1 분 동안 균질한 후 $\mathrm{pH}$ meter 
(SevenEasy pH, Mettler-Toledo GmbH \& Co., Switzerland)로 측정하였다.

\section{4. 지방산화 측정}

지방산화는 Sinnhuber와 $\mathrm{Yu}(1997)$ 의 2-thiobarbituric acid reactive substances (TBARS) 방법에 따라 측정하였다. 시료 0.4 $\mathrm{g}$ 을 pyrex tube에 정량하여 항산화제 $(3 \%(\mathrm{w} / \mathrm{w})$ BHT- $3 \%(\mathrm{w} / \mathrm{w})$ BHA-54\%(w/w) propylene glycol-40\%(w/w) Tween 20) 200 $\mu \mathrm{L}, 1 \%(\mathrm{w} / \mathrm{v}) \mathrm{TBA}-0.3 \%(\mathrm{w} / \mathrm{v}) \mathrm{NaOH}$ 용액 $3 \mathrm{~mL}$ 와 $2.5 \%(\mathrm{w} / \mathrm{v})$ TCA-3.6 mM HCl 용액 $17 \mathrm{~mL}$ 을 첨가하여 $100^{\circ} \mathrm{C}$ water bath에 서 30 분 동안 가열한 후 얼음물에서 15 분 동안 냉각하였다. 부유 물을 분리해내기 위해 상등액 $5 \mathrm{~mL}$ 와 chloroform $3 \mathrm{~mL}$ 을 $20^{\circ} \mathrm{C}$ /4,000 rpm(GS-6R Centrifuge, Beckman Instruments, Inc., $\mathrm{USA}$ )에서 30 분 동안 원심분리한 다음 상층액의 흡광도를 532 nm(UV-2401PC, Shimadzu Corp., Japan)에서 TBARS의 흡광 도를 측정하였다. 또한 당, 향신료, 기타 성분들에 의한 탁도를 제 거하기 위해 $440 \mathrm{~nm}$ 와 $600 \mathrm{~nm}$ (Hodges 등, 1999)에서 흡광도를 측정하였으며, 최종 결과는 측정된 흡광도를 이용하여 시료 $1 \mathrm{~kg}$ 당 $\mathrm{mg}$ malonaldehyde (MA)로 산출하였다.

\section{5. 색깔 측정}

시료의 색깔은 칼로 자른 단면을 식품 포장용 선상 저밀도 폴리 에틸렌 랩(3M Co., Korea)으로 덮은 후 chroma meter (CR-400, Konica Minolta Sensing, Inc., Japan)를 이용하여 CIE (Commision Internationale de Leclairage, 2004) L*(lightness), $\mathrm{a}^{*}$ (redness) 및 $\mathrm{b}^{*}$ (yellowness) 값을 측정하였다. 이때 chroma meter의 보정에 이용한 백색 표준판 $\left(2^{\circ}\right.$ observer; illuminant $\mathrm{C}$ : $\mathrm{Y}=93.6, \mathrm{x}=0.3134, \mathrm{y}=0.3194)$ 의 색도는 $\mathrm{L}^{*}=97.46, \mathrm{a}^{*}=$ 0.08 및 $\mathrm{b}^{*}=1.81$ 이었다.

\section{6. 통계분석}

본 실험을 통해 얻은 자료들은 $\operatorname{SPSS}(2005)$ program의 ANOVA (analysis of variance)에 의해 분석하였으며, 각 평균들 간의 유의성 차이는 Duncan's multiple range test에 의해 5\% 수 준에서 검증하였다.

\section{결과 및 고찰}

\section{1. 총균수 및 젖산균수 비교}

아질산염과 녹차 추출물의 첨가에 따른 김치 발효 소시지의 숙성 중 총균수 및 젖산균수를 비교한 결과는 Fig. 1과 같다. 김치 발효 소시지의 총균수와 젖산균수는 모든 숙성기간 동안 아질산염과 녹
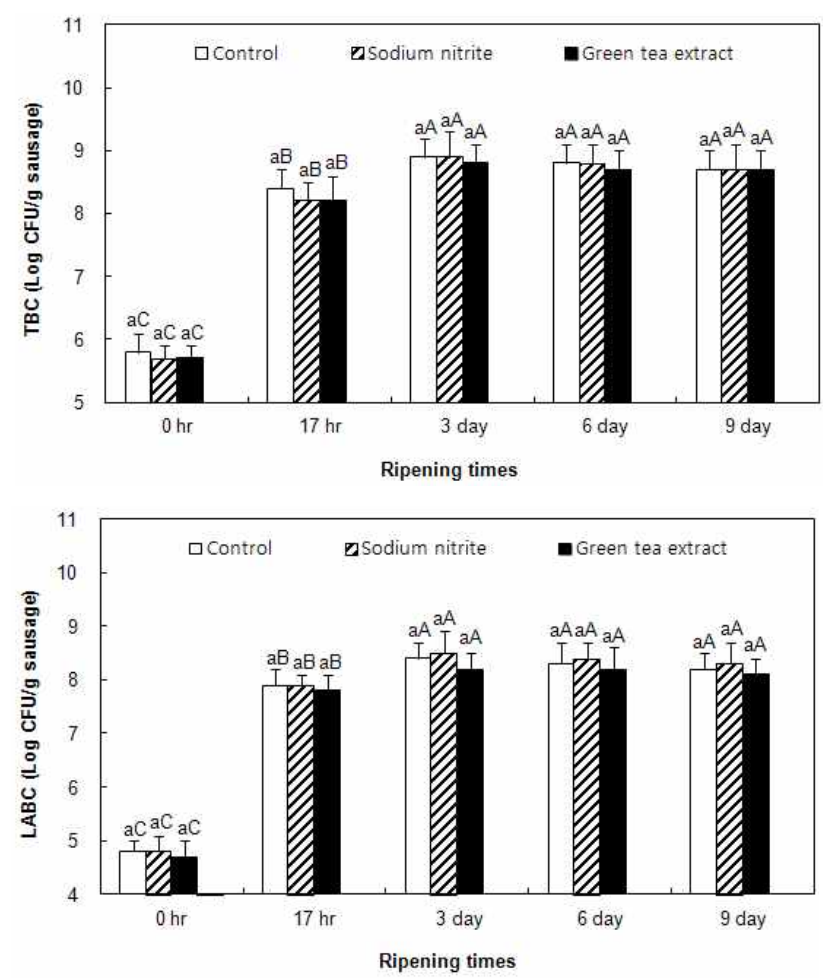

Fig. 1. Comparison of the total bacteria count (TBC) and lactic acid bacteria count (LABC) in Kimchifermented sausages added with sodium nitrite and green tea extract during ripening.

Values are means \pm S.D. ${ }^{a-c}$ Different letters indicate significant differences among treatments within the same ripening time $(\mathrm{p}<0.05)$. ${ }^{\mathrm{A}-\mathrm{E}}$ Different letters indicate significant differences among ripening times within the same treatment $(\mathrm{p}<0.05)$.

차 추출물의 첨가에 따른 유의적인 차이가 나타나지 않았다 ( $>0.05)$. 숙성기간 동안 실험 소시지들의 총균수 변화를 보면, 최 초 0 시간의 5.7 5.8 Log CFU/g sausage에서 발효 종료인 17시 간째에 8.2 8.4 Log $\mathrm{CFU} / \mathrm{g}, 3$ 일째에 $6.2 \mathrm{Log} \mathrm{CFU} / \mathrm{g}$ 및 7.4 7.5 Log CFU/g으로 유의적으로 증가한 후 $(\mathrm{p}<0.05)$ 6일째 이후부터는 8.7 8.8 Log CFU/g 및 $8.7 \mathrm{Log} \mathrm{CFU} / \mathrm{g}$ 으로 유의적 인 변화를 보이지는 않았으나, 감소하는 경향을 나타내었다. 젖산 균 역시 숙성기간 동안 총균수와 동일한 결과를 나타내어 숙성 0 시간째에 4.7 4.8 Log CFU/g sausage에서 3일째까지 8.2 8.5 $\log \mathrm{CFU} / \mathrm{g}$ 으로 유의적으로 증가한 후 $(\mathrm{p}<0.05)$ 최종 9 일째까지는 8.1 8.3 $\mathrm{Log} \mathrm{CFU} / \mathrm{g}$ 으로 감소하는 경향을 보였다. 본 실험결과와 동일하게 $\mathrm{Kim}$ 등 (2002)의 유화형 소시지의 $30^{\circ} \mathrm{C} / 40$ 일 저장 실험 에서도 아질산염과 녹차 추출물의 첨가에 따른 총균수의 차이가 크 게 나타나지 않았다고 보고되었으며, Shin 등 (2009)의 연구에서는 녹차 추출물이 젖산균(Lactobacillus 및 Leuconostoc)의 생장에 영향을 미치지 않았다고 동일하게 보고되었다. 또한 본 실험에서 김치 발효 소시지의 주요 생장균은 $\operatorname{Lim}$ 등 (1989)의 발효온도별 
$\left(5^{\circ} \mathrm{C}, 15^{\circ} \mathrm{C}\right.$ 및 $\left.25^{\circ} \mathrm{C}\right)$ 김치균 동정에 관한 연구로 미루어 봤을 때, 대부분 Lactobacillus 및 Leuconostoc과 같은 젖산균일 것으로 사 료된다. 하지만 총균수가 젖산균수에 비해 높게 나타난 이유는 김 치에는 젖산균 외에도 Aerococcus, Bacillus, Cryptococcus, Enterobacter, Sphingomonas, Stenotrophomonas 등(Chang 등, 2011; Shin 등, 1996)과 같은 다른 박테리아가 서식하기 때문이 다.

\section{2. $\mathrm{pH}$ 비교}

김치 발효 소시지의 $\mathrm{pH}$ (Fig. 2)는 모든 숙성기간 동안 아질산염 과 녹차 추출물의 첨가에 따른 유의적인 차이를 보이지 않았다 $(\mathrm{p}>0.05)$. 숙성기간 동안 실험 소시지들의 $\mathrm{pH}$ 변화는 6 일을 제외 한 모든 기간들에서 유의적인 감소를 보였으며 $(\mathrm{p}<0.05)$, 최초 0 시 간째의 5.53 5.54에서 17시간째까지는 4.90 4.91로 감소한 후 최 종 9일째까지는 4.35 4.36으로 감소하였다. 본 실험결과에서 아질 산염과 녹차 추출물이 김치 발효 소시지의 숙성 중 $\mathrm{pH}$ 에 영향을 미치지 못했던 이유는 이들의 첨가가 젖산균의 생장에 영향을 미치 지 못했기 때문이다. 발효 소시지의 숙성 중 $\mathrm{pH}$ 는 스타터 미생물 인 젖산균이 증식함에 따라 이들의 발효 대사에 의해 젖산이 축적 됨으로서 감소된다(Lücke, 1994). American Meat Institute (1982)는 발효 소시지란 미생물의 작용에 의해 $\mathrm{pH}$ 가 5.3 미만으로 저하된 분쇄 육제품이라고 정의하였으며, 발효 소시지의 낮은 $\mathrm{pH}$ 는 발색 및 풍미 증진(Lücke, 1994), E. coli, Salmonellae, Staphylococcus aureus 등의 유해 식중독균 억제(Schillinger와 Lücke, 1989; Tilden 등, 1996), 저장성 증진 (Leistner와 Rodel, 1975)에 매우 중요하다. 따라서 본 실험의 김치 발효 소시지는 숙 성 17 시간째에 $\mathrm{pH}$ 가 5.0 미만으로 저하되었으므로 미생물 측면에 서 안전하고 저장성이 높을 것으로 사료된다.

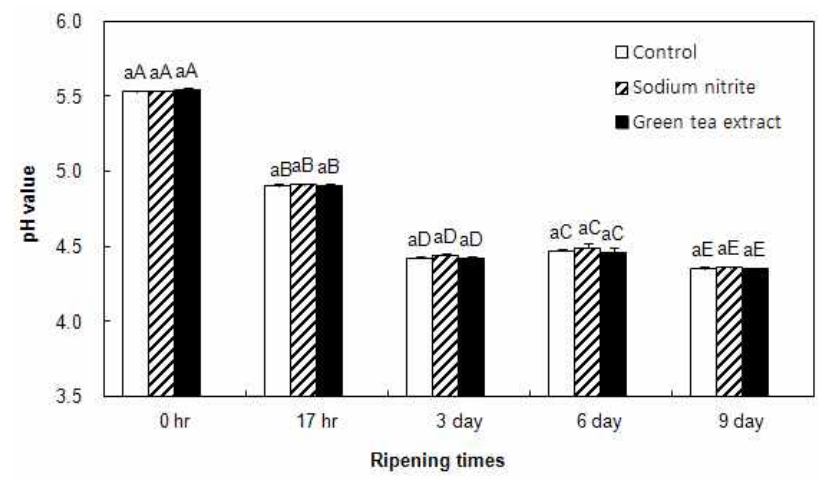

Fig. 2. Comparison of the $\mathrm{pH}$ value in Kimchifermented sausages added with sodium nitrite and green tea extract during ripening.

Values are means \pm S.D. ${ }^{\mathrm{a}-\mathrm{c}}$ Different letters indicate significant differences among treatments within the same ripening time $(\mathrm{p}<0.05)$. ${ }^{\mathrm{A}-\mathrm{E}}$ Different letters indicate significant differences among ripening times within the same treatment $(\mathrm{p}<0.05)$.

\section{3. 지방산화 비교}

김치발효 소시지의 지방산화 지표로 측정한 TBARS 함량(Fig. $3)$ 은 숙성 17 시간째부터 아질산염 및 녹차 추출물 첨가구들이 대 조구 (무첨가구)보다 유의적으로 낮게 나타났다 $(\mathrm{p}<0.05)$. 하지만 숙성 6 일째부터 녹차 추출물 첨가구가 아질산염 첨가구에 비해 유 의적으로 높은 함량을 보였다 $(\mathrm{p}<0.05)$. 숙성기간 동안 실험 소시 지들의 TBARS 변화를 보면, 최초 0 시간째에 $1.21 \sim 1.25 \mathrm{mg}$ $\mathrm{MA} / \mathrm{kg}$ sausage에서 계속적으로 유의적인 증가를 보여 $(\mathrm{p}<0.05)$ 최종 9일째에는 4.08 7.95 mg MA/kg sausage으로 약 3.4 6.4배 의 높은 수준을 보여 주었다. Bozkurt (2006)는 녹차 추출물 300 $\mathrm{ppm}$ 을 첨가시 발효 소시지의 숙성 중 TBARS 생성이 대조구 (무 첨가구) 보다 억제되었다고 본 실험결과와 동일하게 보고하였다. 이러한 이유는 본 실험에 이용된 녹차 추출물에는 $20 \%$ 이상의 catechin 성분들이 함유되어 있었으며, 이들은 유리 래디칼 소거력 과 금속 이온 봉쇄력 및 환원력으로 인해 강력한 항산화력을 가지 고 있기 때문이다(Park 등, 2009). 또한 아질산염의 경우 가공 제 품의 필수적인 첨가제인 소금으로 인해 유리되는 철 이온을 봉쇄하 고, 불포화지방산을 안정화시킴으로서 지방산화를 억제한다(Freybler 등, 1993; Kanner, 1994). 특히, 아질산염 $150 \mathrm{ppm}$ 이 천연 폴리 페놀 추출물 (leek) $8,400 \mathrm{ppm}$ 및 $16,800 \mathrm{ppm}$ 보다 발효 소시지 의 숙성 중 TBARS 생성을 현저하게 억제시켰다는 Tsoukalas 등 (2011)의 보고와 본 실험결과로 미루어 밨을 때, 아질산염의 항산 화력은 폴리페놀 성분을 함유한 녹차 추출물 등의 천연 항산화제보 다 우수한 것으로 사료된다.

\section{4. 색깔 비교}

김치 발효 소시지의 색깔 항목 중 L* 값(Fig. 4)은 모든 숙성기

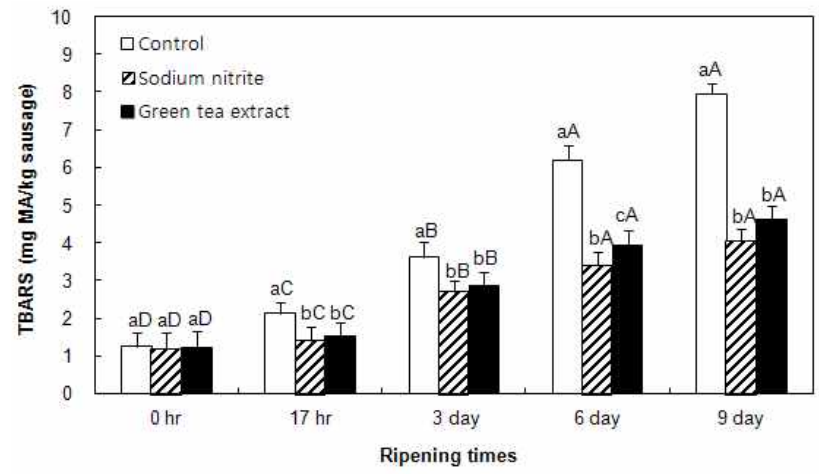

Fig. 3. Comparison of the TBARS content in Kimchifermented sausages added with sodium nitrite and green tea extract during ripening.

Values are means \pm S.D. ${ }^{\mathrm{a}-\mathrm{c}}$ Different letters indicate significant differences among treatments within the same ripening time $(\mathrm{p}<0.05)$. ${ }^{\mathrm{A}-\mathrm{E}}$ Different letters indicate significant differences among ripening times within the same treatment $(\mathrm{p}<0.05)$. 

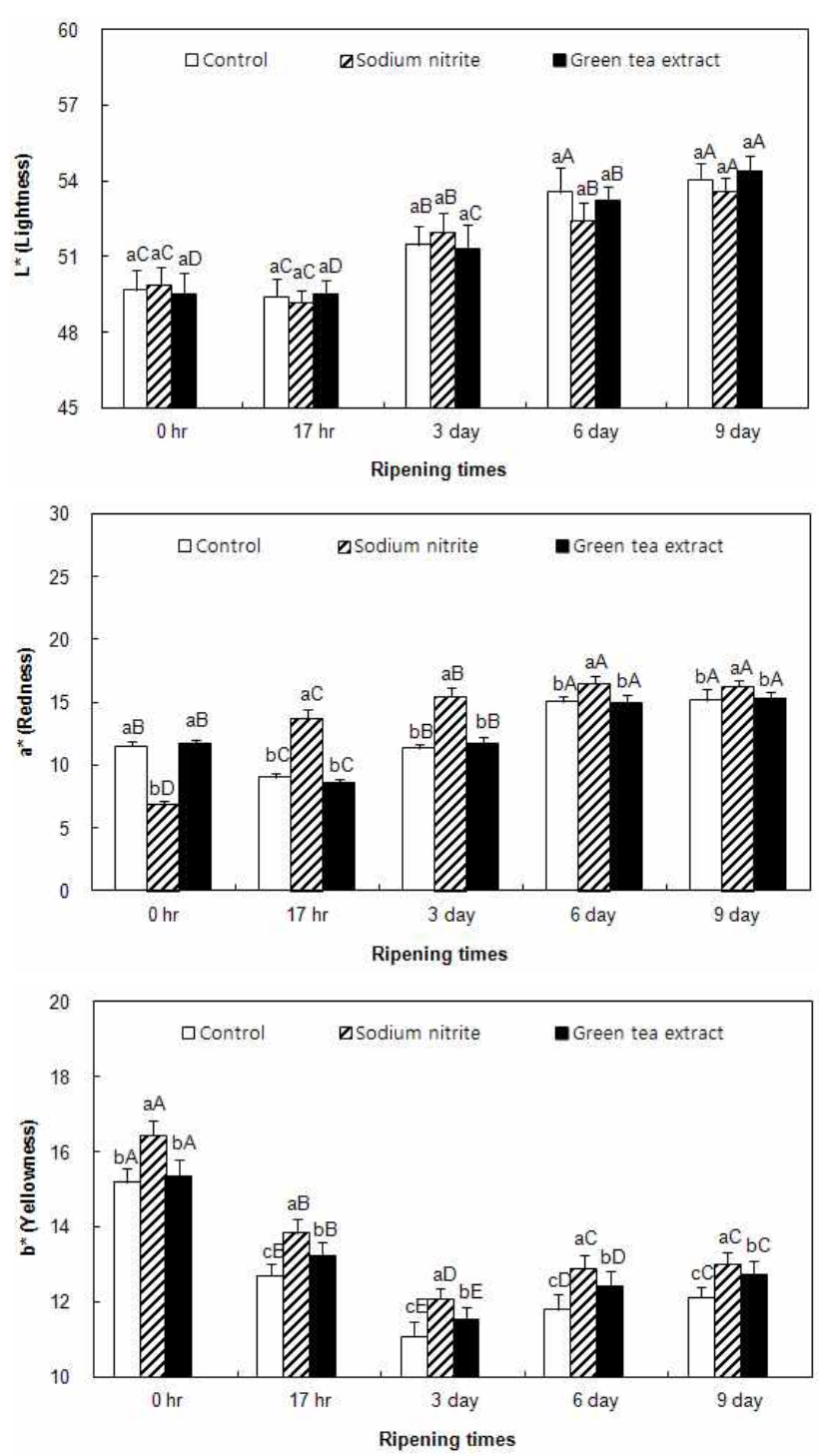

Fig. 4. Comparison of the color in Kimchi-fermented sausages added with sodium nitrite and green tea extract during ripening.

Values are means \pm S.D. ${ }^{a-c}$ Different letters indicate significant differences among treatments within the same ripening time $(\mathrm{p}<0.05)$. ${ }^{\mathrm{A}-\mathrm{E}}$ Different letters indicate significant differences among ripening times within the same treatment $(\mathrm{p}<0.05)$.

간 동안 아질산염과 녹차 추출물의 첨가에 따른 유의적인 차이를 보이지 않았다 $(\mathrm{p}>0.05)$. 하지만 실험 소시지들의 $\mathrm{L}^{*}$ 값은 숙성 0 시간째에 49.52 49.87에서 3일째부터 급격히 증가하여 9일째에는 53.59 54.40의 수준을 보여 주었다. a* 값 (Fig. 4)은 숙성 0시간 째에 녹차 추출물 첨가구와 대조구가 각각 11.71 및 11.55 로 6.91 인 아질산염 첨가구에 비해 유의적으로 높게 나타났으나 $(\mathrm{p}<0.05)$, 17 시간째부터는 오히려 역전되어 녹차 추출물 첨가구와 대조구가 유의적으로 낮은 수치를 보였다 $(\mathrm{p}<0.05)$. 하지만 녹차 추출물 첨
가구와 대조구의 $\mathrm{a}^{*}$ 값들간에 유의적인 차이는 보이지 않았다 $(\mathrm{p}>0.05)$. 숙성 중 실험 소시지들의 $\mathrm{a}^{*}$ 값의 변화는 녹차 추출물 첨가구와 대조구의 경우 숙성 6일째에 유의적으로 증가했던 반면 $(\mathrm{p}<0.05)$, 아질산염 첨가구의 경우 숙성 17 시간째부터 6 일까지 유 의적인 증가를 보였다 $(\mathrm{p}<0.05) . b^{*}$ 값(Fig. 4)은 모든 숙성기간 동안 녹차 추출물 첨가구와 대조구가 아질산염 첨가구에 비해 유의 적으로 낮게 나타났으며 $(\mathrm{p}<0.05)$, 녹차 추출물 첨가구의 경우 숙 성 17시간째부터 대조구보다 유의적으로 높은 수치를 보여 주었다 $(\mathrm{p}<0.05)$. 숙성 중 $\mathrm{b}^{*}$ 값의 변화는 모든 처리구들이 숙성 3 일째까 지 유의적으로 감소하였다가 $(\mathrm{p}<0.05)$ 이후 증가하는 것으로 나타 났다. $\operatorname{Kim}$ 등 (2010)은 간장 양념 계육의 $1^{\circ} \mathrm{C} / 16$ 일 저장 실험에서 $1,000 \mathrm{ppm}$ 및 $2,000 \mathrm{ppm}$ 의 녹차 추출물을 첨가시 $\mathrm{L}^{*}, \mathrm{a}^{*}, \mathrm{~b}^{*}$ 값들 모두 대조구 (무첨가구)에 비해 저장기간 동안 낮게 유지되었 다고 보고하였으며, Bozkurt (2006) 역시 발효 소시지에 관한 연구 에서 $300 \mathrm{ppm}$ 의 녹차 추출물을 첨가시 $\mathrm{L}^{*}, \mathrm{a}^{*}, \mathrm{~b}^{*}$ 값들 모두 숙 성기간 동안 낮게 유지되었다고 보고하였다. 한편 Deda 등 (2007) 은 프랑크푸르트 소시지에 관한 연구에서 $150 \mathrm{ppm}$ 의 아질산염을 첨가시 대조구 (무첨가구)에 비해 높은 $\mathrm{L}^{*}$ 및 $\mathrm{a}^{*}$ 값과 낮은 $\mathrm{b}^{*}$ 값 을 보였다고 보고한 반면, Tsoukalas 등 (2011)은 발효 소시지에 $150 \mathrm{ppm}$ 의 아질산염을 첨가했을 때, 낮은 $\mathrm{L}^{*}$ 값과 높은 $\mathrm{a}^{*}$ 및 $b^{*}$ 값을 보였다고 보고하였다. 따라서 본 실험과 선행연구 결과들 을 종합해 밨을 때, 아질산염의 경우 본래 가지고 있는 발색 효과 로 인해 $\mathrm{a}^{*}$ 값을 증가시키지만, 녹차 추출물의 경우 $\mathrm{a}^{*}$ 값을 향상 시키지 않는 것으로 사료된다.

\section{요 약}

본 연구는 김치 발효 소시지(Kimchi-fermented sausage)에서 아질산염과 녹차 추출물이 미생물 및 이화학적 품질 특성에 미치는 효과를 비교하고자 실시하였다. 실험 소시지는 $24^{\circ} \mathrm{C} / \mathrm{RH} 89 \%$ 에서 17 시간 동안 발효시킨 후 $10^{\circ} \mathrm{C} / \mathrm{RH} \quad 70 \sim 80 \%$ 에서 9일간 건조시켰 다. 총균수, 젖산균수 및 $\mathrm{pH}$ 는 최종 9일째에 각각 $8.7 \mathrm{Log}$ CFU/g sausage, 8.1 8.3 Log CFU/g sausage 및 4.35 4.36이었 으며, 숙성기간 동안 처리구들간에 차이를 보이지 않았다. 지방산 화(TBARS)는 아질산염과 녹차 추출물의 첨가에 의해 억제되었으 나, 녹차 추출물 첨가구가 아질산염 첨가구보다 낮은 효과를 보였 다. 색깔은 녹차 추출물 첨가구가 숙성기간 동안 대조구 (무첨가구) 보다 높은 황색도 $\left(\mathrm{b}^{*}\right)$ 를 유지하였으나, 아질산염 첨가구의 경우 다 른 처리구들보다 높은 적색도 $\left(\mathrm{a}^{*}\right)$ 와 황색도 $\left(\mathrm{b}^{*}\right)$ 를 유지하였다. 따 라서 녹차 추출물의 첨가에 의해 김치 발효 소시지의 지방산화 안 정성이 증가되었으나, 아질산염에 비해 지방산화 안정성 및 색깔 안정성이 낮았다. 하지만 녹차 추출물과 아질산염 모두 젖산균의 생장에 영향을 미치지 못하였다.

(주제어: 녹차 추출물, 아질산염, 김치 발효 소시지, 지방산화, 색 깔, 젖산균) 


\section{인 용 문 헌}

American Meat Institute. 1982. Good manufacturing practices, fermented dry and semi-dry sausage. American Meat Institute, Washington, D.C., U.S.A.

Bañón, S., Diaz, P., Rodriguez, M., Garrido, M. D. and Price, A. 2007. Ascorbate, green tea and grape seed extracts increase the shelf life of low sulphite beef patties. Meat Sci. 77:626-633.

Bloukas, J. G., Arvanitoyannis, I. S. and Siopi, A. A. 1999. Effect of natural colourants and nitrites on colour attributes of frankfurters Meat Sci. 52:257-265.

Bozkurt, H. 2006. Utilization of natural antioxidants: green tea extract and Thymbra spicata oil in Turkish dry-fermented sausage. Meat Sci. 73:442-450

Cassens, R. G. 1997. Residual nitrite in cured meat. Food Technol 51:53-55.

Chang, J. Y., Choi, Y. R. and Chang, H. C. 2011. Change in the microbial profiles of commercial Kimchi during fermentation. Korean J. Food Preserv. 18:786-794.

Choi, J. W., Park, J. H., Ji, S. T., Choi, O. B. and Shin, H. K. 1999. Antigenotoxic effect of dominant bacterial isolates from Kimchi in vitro. Korean J. Food Sci. Technol. 31:1071-1076.

Chow, C. K. and Hong, C. B. 2002. Dietary vitamin E and selenium and toxicity of nitrite and nitrate. Toxicol. 180:195-207.

Chu, D. -C. and Juneja, L. R. 1997. General chemical composition of green tea and its infusion. In Chemistry and Applications of Green Tea, L. R. Juneja, D. -C. Chu and M. Kim(Eds.), CRC Press, Boca Raton, U.S.A., pp. 13-22.

CIE. 2004. Technical Report: colorimetry. 3rd ed, Commision Internationale de Leclairage Central Bureau, Publication 8, Vienna, Austria.

Coyle, C. H., Philips, B. J., Morrisroe, S. N., Chancellor, M. B. and Yoshimura, N. 2008. Antioxidant effects of green tea and its polyphenols on bladder cells. Life Sci. 83:12-18

Deda, M. S., Bloukas, J. G. and Fista, G. A. 2007. Effect of tomato paste and nitrite level on processing and quality characteristics of frankfurters. Meat Sci. 76:501-508.

Fleybler, L. A., Gray, J. I., Asghar, A., Boreen, A. M., Pearson, A. M. and Buckley, D. J. 1993. Nitrite stabilization of lipids in cured pork. Meat Sci. 33:85-96.

Francis, F. J. 1987. Lesser-known food colorants. Food Technol. 41:62-68.

Hernández-Hernández, E., Ponce-Alquicira, E., Jaramillo-Flores, M. E. and Legarreta, I. G. 2009. Antioxidant effect of rosemary (Rosmarinus officinalis L.) and oregano(Origanum vulgare L.) extracts on TBARS and color of model raw pork batters. Meat
Sci. 81:410-417.

Hodges, D. M., DeLong, J. M., Forney, C. F. and Prange, R. K. 1999. Improving the thiobarbituric acid-reactive-substances assay for lipid peroxidation in plant tissues containing anthocyanin and other interfering compounds. Planta 207:604-611.

Hugas, M. and Monfort, J. M. 1997. Bacterial starter cultures for meat fermentation. Food Chem. 59:547-554.

Jo, C., Son, J. H., Son, C. B. and Byun, M. W. 2003. Functional properties of raw and cooked pork patties with added irradiated, freeze-dried green tea leaf extract powder during storage at $4{ }^{\circ} \mathrm{C}$. Meat Sci. 64:17-33.

Kang, S. M., Muhlisin, Choi, W. H., Cho, S. H., Kim, D. H. and Lee, S. K. 2011. Effect of Rhus verniciflua Stokes extract and gallic acid on the quality characteristics of Hanwoo (Korean cattle) beef patties stored in high oxygen-modified atmosphere package. 57th Int. Cong. Meat Sci. Technol., Ghent, Belgium, pp. 210.

Kanner, J. 1994. Oxidative processes in meat and meat products: quality implications. Meat Sci. 36:169-189.

Kim, G. D., Jeong, J. Y., Jung, E. Y., Seo, H. W., Kim, S. H., Kang, G. H., Choi, Y. H. and Joo, S. T. 2010. Effects of addition of green tea extracts on physicochemical properties of seasoned chicken with soy sauce during cold storage. Korean J. Poult. Sci. 37:265-273.

Kim, S. M., Cho, Y. S., Sung, S. K., Lee, I. G., Lee, S. H. and Kim, D. G. 2002. Developments of functional sausage using plant extracts from pine needle and green tea. Korean J. Food Sci. Ani. Resour. 22:20-29.

Kuroda, Y. and Hara, Y. 1999. Antimutagenic and anticarcinogenic activity of tea polyphenols. Mut. Res. 436:69-97.

Lee, S. K., Yoo, I. J., Kim, Y. B. and Kim, K. S. 1990. Fermentation of sausage using Kimchi. Korean J. Anim. Sci. 32:707-714.

Lee, Y. O. and Cheigh, H. S. 1995. Antioxidative effect of Kimchi on the lipid oxidation of cooked meat. J. Korean Soc. Food Nutr. 24:1005-1009.

Leistner, L. and Rodel, W. 1975. The significance of water activity for microorganisms in meats. In Water Relations of Foods, R. B. Duckworth (Ed.), Academic Press, London, U.K., pp. 309-323.

Lim, C. R., Park, H. K. and Han, H. U. 1989. Reevaluation of isolation and identification of gram-positive bacteria in Kimchi. Korean J. Microbiol. 27:404-414.

Lücke, F. K. 1994. Fermented meat products. Food Res. Int. 27:299-307.

Lücke, F. K. 1998. Fermented sausages. In Microbiology of Fermented Foods. B. J. B. Wood (Ed.), Blackie Academic and 
Professional, New York, U.S.A., pp. 441-483.

McCarthy, T. L., Kerry, J. P., Kerry, J. F., Lynch, P. B. and Buckley, D. J. 2001. Assessment of the antioxidant potential of natural food and plant extracts in fresh and previously frozen pork patties. Meat Sci. 57:177-184.

Mirvish, S. S., Reimers, K. J., Kutler, B., Chen, S. C., Haorah, J., Morris, C. R., Grandjean, A. C. and Lyden, E. R. 2000. Nitrate and nitrite concentrations in human saliva for men and women at different ages and times of the day and their 286 consistency over time. Eur. J. Can. Prev. 9:335-342.

Mitsumoto, M., O'Grady, M. N., Kerry, J. P. and Buckley, D. J. 2005. Addition of tea catechins and vitamin $\mathrm{C}$ on sensory evaluation, colour and lipid stability during chilled storage in cooked or raw beef and chicken patties. Meat Sci. 69:773-779.

Mohamed, H. M. H., Mansour, H. A. and Farag, M. D. E. -D. H. 2011. 9The use of natural herbal extracts for improving the lipid stability and sensory characteristics of irradiated ground beef. Meat Sci. 87:33-39.

Noh, K. A., Kim, D. H., Choi, N. S. and Kim, S. H. 1999. Isolation of fibrinolytic enzyme producing strains from Kimchi. Korean J. Food Sci. Technol. 31:219-223.

Park, K. R., Lee, S. G., Nam, T. G., Kim, Y. J., Kim, Y. R. and Kim, D. O. 2009. Comparative analysis of catechins and antioxidant capacity in various grades of organic green teas grown in Boseong, Korea. Korean J. Food Sci. Technol. 41: $82-86$.

Park, K. Y. and Cheigh, H. S. 2000. Antimutagenic and anticancer effect of lactic acid and bacteria isolated from Kimchi. Proc. Int'l Symp. Microorganism and Health, Seoul, Korea.

Schillinger, U. and Lücke, F. K. 1989. Einsatz von milchsäurebakterien als schutzkulturen bei fleischerzeugnissen. Fleischwirt. 69:879882 .

Sheo, H. J. and Seo, Y. S. 2004 The effects of dietary Chinese cabbage Kimchi juice on the lipid metabolism and body weight gain in rats fed high-calories-diet. J. Korean Soc. Food Sci. Nutr. 33:91-100.

Shin, D. W., Kim, M. S., Han, J. S., Lim, D. K. and Bak, W. S.
1996. Changes of chemical composition and microflora in commercial Kimchi. Korean J. Food Sci. Technol. 28:137-145.

Shin, Y. H., Oh, B. T., Choi, S. G., Heo, H. J., Lee, S. C. and Cho, S. H. 2009. Antimicrobial activity of an aqueous extract of green tea against food putrefactive microorganisms. Korean J. Food Preserv. 16:392-399.

Sinnhuber, R. O. and Yu, T. C. 1977. The 2-thiobarbituric acid reaction, an objective measure of the oxidative deterioration occurring in fats and oils. J. Jap. Soc. Fish. Sci. 26:259-267.

SPSS. 2005. SPSS 14.0 for Windows Evaluation Version, SPSS Inc., Illinois, U.S.A.

Tilden Jr., J., Young, W., McNamara, A. M., Custer, C., Boesel, B., Lambert-Fair, M. A., Majkowski, J., Vugia, D., Werner, S. B., Hollingsworth, J. and Morris Jr., J. G. 1996. A new route of transmission for Escherichia coli: infection from dry fermented salami. Am. J. Pub. Heal. 86:1142-1145.

Tsoukalas, D. S., Katsanidis, E., Marantidou, S. and Bloukas, J. G. 2011. Effect of freeze-dried leek powder (FDLP) and nitrite level on processing and quality characteristics of fermented sausages. Meat Sci. 87:140-145.

Wanasundara, U. N. and Shahidi, F. 1996. Stabilization of seal blubber and menhaden oil with green tea catechins. J. Am. Oil Chem. Soc. 73:1183-1190.

Yang, H. S., Jeong, J. Y., Lee, J. I., Yun, I. R., Joo, S. T. and Park, G. B. 2006. Effects of green tea extracts on quality characteristics and reduced nitrite content of emulsion type sausage during storage. Korean J. Food Sci. Ani. Resour. 26:454463.

Yu, M. H., Im, H. G., Im, N. K., Hwang, E. Y., Choi, J. H., Lee, E. J., Kim, J. B., Lee, I. S. and Seo, H. J. 2009. Antihypertensive activities of Lactobacillus isolated from Kimchi. Korean J. Food Sci. Technol. 41:428-434.

Zaveri, N. T. 2006. Green tea and its polyphenolic catechins: medical uses in cancer and noncancer applications. Life Sci. 78:20732080.

(Received Jun. 4, 2012; Revised Aug. 21, 2012; Accepted Aug. 24, 2012) 